\title{
Assessing the Impact of ASEAN+3 Free Trade Agreements on ASEAN's Trade Flows: A Gravity Model Approach ${ }^{1}$
}

\author{
Nguyen Anh Thu \\ Vu Van Trung \\ Le Thi Thanh Xuan \\ University of Economics and Business, Vietnam National University Hanoi, Vietnam \\ Email: thuna@vnu.edu.vn
}

\section{Doi:10.5901/mjss.2015.v6n6p394}

\begin{abstract}
This paper employs the gravity model with panel data to examine the impact of ASEAN+3 free trade agreements on ASEAN's trade flows in the period 2000 - 2013. Estimated results indicate that GDP, GDP per capita, incomegap and distance play a crucial role in bilateral trade among ASEAN members and ASEAN trade volumes with the rest of the world. Additionally, the results reveal that AFTA creates positive and significant trade-creation effects due to tariff eliminations. AFTA has been successful in promoting the bilateral trade not only among ASEAN countries but also between intra-bloc and extra-bloc countries. Conversely, ACFTA, AJCEP negatively affects intra-ASEAN trade and ASEAN's exports to the rest of the world. Meanwhile, ASEAN's imports from the rest of the world are negatively affected by ACFTA and AJCEP. Finally, AKFTA causes trade-diversion effect in terms of exports from member countries to non-member countries of AKFTA. AKFTA can be a positive factor in promoting exports among its members.
\end{abstract}

Keywords: ASEAN+3, Free trade agreement (FTA), Gravity model

\section{Introduction}

Over the last decades, trade liberalization has become an inevitable trend, which is evidenced by the growing number of free trade agreements (FTA) under different regional and global framework. Indeed, it is the establishment of World Trade Organization (WTO) with the involvement of 161 members $^{2}$ that provides a convincing explanation for the benefits of opening markets with all those concerned. However, the Doha round of multilateral trade negotiations initiated in 2001 reached an impasse in 2012 (Evenett, 2012). Since the early of 1990s, the picture of international trade integration has been largely characterized by bilateral and regional free trade agreements (RTAs) (Yang \& Martinez-Zarzoso, 2014). According to WTO statistics, 262 out of 449 RTAs which have been notified by WTO are presently in force by $2015^{3}$.

East Asian is not an exception to the global trend of regional economic integration, characterized by the rapid expansion of international production and distribution networks within the region and the establishment of a number of FTAs. Being now considered as one of the most dynamic regions in the world, East Asian has proved itself that trade liberalization has made significant contributions to the economic growth for all members. Along with the inspiration of the worldwide emergence of regionalism, Association of South East Asian Nations (ASEAN) pioneered by the formation of ASEAN Free Trade Agreement (AFTA) in 1992 with an objective of accelerating trade flows within the market of approximately 600 million people. Additionally, ASEAN has paid much effort towards realizing ASEAN Economic Community by the end of 2015 to help ASEAN become a single market and production base, a highly competitive economic region and closer integration into the global economy. After the economic crisis in 1997, East Asian countries became more aware of the regional economic integration, accompanied by the economic dialogue and cooperation between 10 members of ASEAN and three Northeast Asian economies including China, Japan and the republic of Korea (hereafter referred as ASEAN+3). In particular, the FTAs for liberalization of trade in goods between ASEAN and China,

\footnotetext{
1 This article has been done under the research project QGTÐ 13.22 "Assessing the economic integration process of Vietnam in ASEAN and ASEAN + 3 from 2013 to 2015 " with the support from Vietnam National University.

${ }^{2}$ https://www.wto.org/english/thewto_e/whatis_e/tif_e/org6_e.htm, accessed on May 15, 2015.

3https://www.wto.org/english/tratop_e/region_e/region_e.htm , accessed on May 16, 2015
} 
republic of Korea and Japan were officially signed in 2004, 2006 and 2008, respectively. Obviously, the formation of FTAs with three largest economies in the Northeast of Asia provides ASEAN with an opportunity of accessing the huge markets and helps enhancing economic growth of ASEAN members as well as the whole region. Over the last three decades, ASEAN has obtained remarkable achievements in economic growth, which is clearly explained by the fact that its contribution to world GDP has doubled (ERIA, 2012). Indeed, the trade integration under ASEAN+3 FTAs framework helps ASEAN to maintain its economic growth by approaching the potential markets in the region, in the context that the main traditional export markets of G7decelerates due to the burdens of huge debts and deficits (ASEAN Secretariat and World Bank, 2013). In general, the establishment of those FTAs is the fundamental step towards strengthening economic and trade cooperation among the 13 economies, accounting for more than one-fifths of world GDP4.

In the light of significant progress in ASEAN trade liberalization, this paper examines the specific effects of ASEAN+3 FTAs including AFTA and FTAs between ASEAN and China, the republic of Korea, Japan (hereafter referred as ACFTA, AKFTA and AJCEP, respectively). In particular, the study investigates the impact of those FTAs on ASEAN intra-regional trade and ASEAN's trade flows with the rest of the world in terms of trade creation and trade diversion effects. According to Vine (1950), trade creation occurs when the tariff elimination within FTAs accelerates trade among member countries. In contrast, trade diversion is defined as the shift in imports from non-member countries of FTAs to member countries which are less efficient. In this regard, many studies have been conducted to identify the particular impacts of FTAs. The notable papers applying the econometric methodology include the work on AFTA by Elliot and Ikemoto (2004), Cabalu and Alfonso (2007), Calvo Pardo, Freund and Ornelas (2009), Shujiro and Okabe (2013), the other papers on ACFTA (Lijun, 2003; Yue, 2004; Tongzon, 2005 and Yang and Martinez-Zarzoso, 2014), on AKFTA (Park and Estrada, 2008). Noticeably, Guilhot (2010) made the first attempt to measure the effects of AFTA, AKFTA and ACFTA on East Asian trade flows but failed to include AJCEP. In general, most of the previous studies evaluate the impacts of ASEAN+3 FTAs separately and the effects are not clear due to short time effect. There is a research gap with limited existing research examining all ASEAN FTAs including AFTA, ACFTA, AKFTA and AJCEP.

Our study contributes to filling this gap by studying the efect of all ASEAN+3 FTAs with the objective of assessing effects of ASEAN+3 FTAs on intra-ASEAN trade, imports from the rest of the world and exports to the rest of the world, separately. In doing so, our study employs the gravity model with bilateral export flow between 10 ASEAN members and their 22 main trading partners, covering the period from 2000 to 2013.

The rest of the paper will be structured as follows. The second part reviews the empirical studies on assessing impacts of FTAs. The third session presents overview about ASEAN trade situation and current state of ASEAN+3 trade integration. Session 4 introduces the methodology for gravity model estimation. Session 5 describes the empirical findings. The last session ends by conclusion.

\section{Literature Review}

There have been intensive discussions in a huge body of literature on the effects of regional integration, especially trade integration. Indeed, empirical studies in this field are of great importance to policymakers as they provide meaningful information and insightful vision about trade policy such as trade creation and trade diversion effects. Truly, the empirical findings on ASEAN FTAs impacts help each country as well as the whole region generate better strategies towards regional trade cooperation. Among a number of econometric papers, gravity model has been popularly adopted for analyzing the effects of FTAs and identifying the determinants explaining bilateral trade flows. For the case of ASEAN FTAs, much attention has been paid to examine their effects on ASEAN trade flows. For example, Elliot and Ikemoto (2004) used a modified gravity equation to examine the effects of AFTA on ASEAN trade flows. The estimation results indicated that AFTA was found to stimulate intra-ASEAN trade. Also, the paper highlighted that ASEAN's export to the rest of the world was not significantly affected from the years immediately following by the establishments of AFTA in 1993. Therefore, the panel data should be extended for the longer period of AFTA's implementation to further consider the trade creation effects. Yang and Martinez-Zarzoso (2014) employed gravity model with an objective of assessing trade creation and trade diversion effects of ACFTA. The paper showed that export flow among members of ACFTA was significantly favored by the reduction in tariff barriers. In addition, the trade creation effects were found in the case of exports of manufactured and chemical goods, when gravity equation was performed at disaggregated level. In contrast, exports of agricultural products, machinery and transport equipment were not promoted by ACFTA. However, the empirical studies examining effects of AKFTA and AJCEP are rather limited. The typical papers include the quantitative analysis using CGE model to estimate the impact of AKFTA by Park \& Estrada (2008), the assessment of AKFTA

${ }^{4}$ Author's calculation based on World Bank database 
impacts on Vietnam's trade by Nguyen Tien Dung (2011) and the analysis of effects of AKFTA on IT industry level by Kim (2005).

Besides, the assessment of the trade effects ofASEAN+3 FTAs all together has been the major concern of many scholars. Guilhot (2010) applied the gravity model with panel data (1985-2007) for bilateral export flows between 12 economies including 10 ASEAN members, China, republic of Korea and their 22 trading partners to assess the impacts of AFTA, ACFTA and AKFTA on East Asian's trade. The paper indicated that while AFTA promoted the intra-regional trade and the exports to the world of East Asia, its impacts in the case of imports were found to be negative. The results also showed that ACFTA and AKFTA had not yet favored East Asia's trade flows. Sudsawasd (2012) built up a gravity equation for bilateral trade flows at disaggregated product level, covering the period of 1996 to 2005 in order to assess the regional trade integration in East Asia. Accordingly, AFTA promoted both trade among members and between members and the rest of the world. Another study by Nguyen Anh Thu, Vu Van Trung and Le Thi Thanh Xuan (2014) performed the gravity model to measure the effects of ASEAN +3 integration on Vietnam's trade flows in fishery sector. In particular, this paper suggested that Vietnam's accession to AFTA, AKFTA and ACFTA was found to have positive impacts on exports of fishery products. Except for AFTA, other FTAs including AKFTA, ACFTA, AJCEP and VJEPA (Vietnam-Japan FTA) had unclear impacts on imports of fishery products.

In summary, gravity model is actually a practical tool for analyzing effects of regional FTAs. East Asian is emerging as one of the most dynamic regions in the world with the establishment various bilateral and regional FTAs, especially ASEAN+3 FTAs which attract much attention of researchers. However, the previous papers mainly focus on AFTA and approach those ASEAN+3 FTAs separately. This paper, therefore, fills in the research gap by assessing impacts of ASEAN+3 FTAs on ASEAN's trade flows.

\subsection{Overview about $A S E A N+3$ trade integration}

Over the past decade, ASEAN's trade value has witnessed a significant increase from 785 billion USD in 2000 to 2479 billion USD in 2013. The average growth rate of the total ASEAN trade volume in the period from $2000-2013$ reached $10.10 \%$. Although intra-ASEAN trade volume increased gradually from 177 billion USD in 2000 to 592 billion USD in 2013, its share in the total ASEAN's trade value was rather limited and did not exceed $25 \%$. Clearly, ASEAN trades more with non-member countries rather than within the region. In particular, the major trading partners of ASEAN include China, Japan, republic of Korea, EU and the US. In 2013, ASEAN+3 trade volume representing ASEAN's trade with China, Japan and the republic of Korea was 714 billion USD, an increase of approximately 3.69 times compared with the figure for 2000. Furthermore, ASEAN+3 countries has always been the leading trading partners which account for $28.81 \%$ of the total ASEAN trade value in 2013. ASEAN - EU trade volume in 2013 reached more than 246 billion USD while the figure between ASEAN and the US was roughly 207 billion USD.

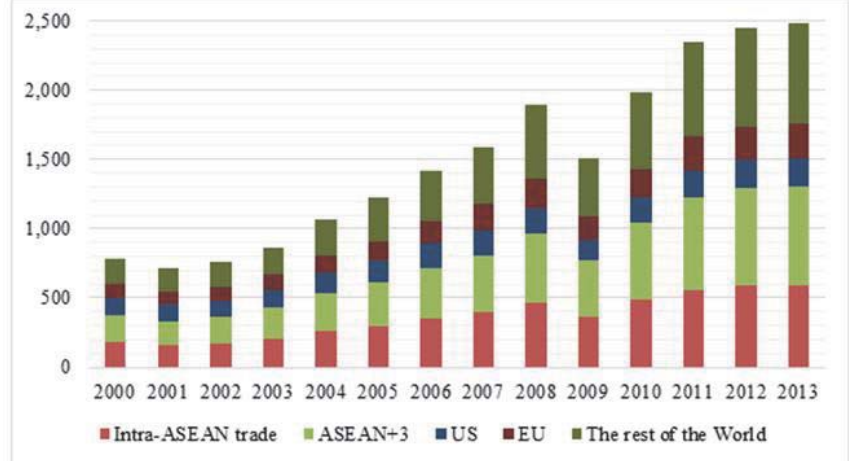

Figure 1. ASEAN trade values from 2000 - 2013 (Unit: billion USD)

Source: UN Comtrade database

In the trend of regional trade integration, ASEAN countries have signed several free trade agreements including AFTA, 
ACFTA, AKFTA and AJCEP. The preferential tariff commitments in the framework of those FTAs have made significant contributions to deeper integration in ASEAN+3.

\subsection{ASEAN Integration}

With the objective of making ASEAN become a single market, ASEAN countries have made great efforts towards realizing the ASEAN Economic Community by the end of 2015. One of the key instruments of integration in ASEAN is the removal of tariff and non-tariff barriers, which is committed in the framework of AFTA. AFTA which was established in 1992 was based on the Agreement on the Common Effective Preferential Tariff Scheme (CEPT). The ASEAN free trade agreement divides products into different tracks including the general exclusion list, the temporary exclusion list and the sensitive list. Each track has its own roadmap of tariff reduction. From 2010 all the applied tariffs for the ASEAN-6 are reduced to 0\%. It is expected that CLMV countries reach that target by 2015 (MUTRAP III, 2010).

\subsection{ASEAN - China Free Trade Agreement (ACFTA)}

ACFTA is the result of a number of negotiations that began in 2002 when the China and ASEAN leaders signed the Framework Agreement on Comprehensive Economic Cooperation between ASEAN and China. According to the agreement on Trade in Goods that was signed in 2004, member countries committed to remove and eliminate the tariff barriers under different schedules. The products in ACFTA are organized into different lists including (1) Early Harvest Program, (2) Normal track (Normal track 1 \& Normal track 2), (3) Sensitive track (containing Sensitive List \& Highly Sensitive List). In particular, Early Harvest Program allowed to strongly reducing tariffs on several agricultural products from HS 01 to HS 08 before the implementation of ACFTA. These products are reduced tariffs over 3 years: to 10\% by 2004, to $5 \%$ by 2005 and $0 \%$ by 2006 . According to the Agreement on Trade in Goods, ASEAN- 6 countries and China had to eliminate tariffs on $90 \%$ of their products by 2010. It is not until 2010 that CLMV countries have to do this. The remaining $10 \%$ of tariff line items are considered as sensitive ones and will be reduced under a slower schedule.

\subsection{ASEAN - Korea Free Trade Agreement (AKFTA)}

AKFTA is organized into three layers of liberalization of which The Agreement on Trade in Goods is considered as the most crucial part of ACFTA. Agreement on Trade in Goods took effect in June 2007. The products in AKFTA are divided into (1) Normal track, (2) Sensitive List and (3) Highly Sensitive List. The schedule for tariff reduction by ASEAN-6 \& Korea in the framework of AKFTA is different from that by CLMV countries. The member countries agreed that ASEAN-6 and Korea would eliminate tariffs of products in Normal track that accounts for nearly $90 \%$ of all goods by 2010 . For products in the Sensitive List, the ASEAN-6 and Korea are committed to reduce the tariff to not more than $20 \%$ by Jan 2012 and subsequently reduce from $0 \%$ to $5 \%$ by Jan 2016. Products in the Highly Sensitive List are sub-divided into 5 groups with different tariff elimination schedules for each product and country group.

\subsection{ASEAN - Japan Comprehensive Economic Partnership Agreement (AJCEP)}

AJCEP is considered as a comprehensive FTA that reached a fairly deep level of commitments in economic regulations (MUTRAP III, 2010). AJCEP that came into force in December 2008 covered many important issues concerning economic integration, such as tariff reduction, trade in goods, rules of origin, sanitary and phyto-sanitary measures, technical barriers to trade, dispute settlement, trade in services, investment and intellectual property rights. About trade in goods, member countries committed that tariff levied on 93\% of imports from ASEAN into Japan will be eliminated within 10 years, while tariff imposed on $50 \%$ of imports from Japan into ASEAN will be removed by ASEAN-6 countries within 10 years.

\section{Methodology}

\subsection{Specification Model}

Along with the speedy growth in trade liberalization, much attention has been devoted to econometric studies on identifying the impact of FTAs on trade flows. Among those papers, gravity model has been popularly employed with dummy variables frequently used as proxy for the participation in FTAs. In general, the basic idea of the model derived 
from Newton's law of gravity states that the volume of trade between two countries is positively related to economic size and negatively correlated with the distance between them.

Following Endoh (1999), Soloaga and Wintersb (2001), Guilhot (2010), Sudsawasd (2012), and Nguyen Anh Thu (2012), this paper develops the gravity equation to investigate effects of ASEAN+3 FTAs on bilateral export flows between 10 ASEAN countries and their 22 main trading partners as follows:

$$
\text { Ln Export } t_{i j}^{t}=a_{i j}+\beta_{1} \text { LnGDP }_{i}^{t}+\beta_{2} \text { LnGDP }_{j}^{t}+\beta_{3} \text { LnGDPPC }_{i}^{t}+\beta_{4} \text { LnGDPPC }_{j}^{t}+\beta_{5} \text { Ln Distance }_{i j}+
$$

$\beta_{6} \operatorname{Ln}$ Incomegap ${ }_{i j}^{t}+\sum_{k=1}^{4} \gamma_{k} F T A 1_{i j k}^{t}+\sum_{k=1}^{4} \alpha_{k} F T A 2_{i j k}^{t}+\sum_{k=1}^{4} \delta_{k} F T A 3_{i j k}^{t}+e_{i j}^{t}(1)$

Where In stands for natural logarithm. The dependent variable,Export $t_{i j}^{t}$ denotes the value of bilateral export from country i to country j in year. $G D P_{i}^{t}$ and $G D P_{j}^{t}$ represent gross domestic product of country i and country j in year t, respectively. GDP captures the economic size of 32 countries in the scope of the study. It is, therefore, denotes the potential demand of the importing countries and potential supply of the exporting countries and is expected to have a positive correlation with bilateral trade flows.GDPPC $C_{i}^{t}$ and $G D P P C_{j}^{t}$ are GDP per capita of country i and country $\mathrm{j}$ in year $\mathrm{t}$, respectively. The average income representing the level of living standards is hypothesized to positively trade value exchanged among countries. Distance ${ }_{i j}$ stands for the weighted distance between the capital city of country $i$ and country j. The estimated coefficient of Distance $_{i j}$ is expected to turn out with negative sign as geographic distance represents the trade costs including transportation and communication costs. Incomegap $p_{i j}^{t}$ is the absolute value of the difference between country i's per capita income and country j's. k take the value from 1 to 4 , representing AFTA, ACFTA, AKFTA and AJCEP, respectively.

Additionally, the dummies variables FTA1, FTA2, FTA3 are included in the gravity equation with an objective of measuring the specific effects of ASEAN+3 FTAs. In particular, FTA1 captures the effect on trade among members of ASEAN. Therefore, this dummy variable take the value of 1 , if both country $i$ and country $j$ belong to the FTA and zero otherwise. In this regard, the positive estimated coefficient represents the trade creation effects as intra-regional trade of ASEAN has been favored by the tariff elimination within the specific FTAs.

FTA2 measures the changes on ASEAN's imports from the rest of the world, takes the value of 1 if only import country $\mathrm{j}$ signs up to FTA and zero otherwise.

A negative coefficient of FTA2 denotes the trade diversion effects as ASEAN's imports have been diverted from non-member countries to member countries due to the implementation of the FTAs. In contrast, the positive sign for this variable implies the trade creation in terms of imports.

FTA3 reflects the changes in ASEAN's exports to the rest of the world and takes the value of 1 if only export country $i$ belongs to FTA and zero otherwise. A positive and statistically significant coefficient of FTA3 indicating the expansion of ASEAN exports to non-member countries of the FTAs is referred as trade creation effects in terms of exports. On the contrary, the negative sign represent the trade diversion of exports from ASEAN countries to nonmember countries of FTAs.

\subsection{Data}

This paper builds up a panel dataset for bilateral trade between 10 ASEAN countries and ASEAN's top 22 trading partners, covering the period from 2000 to 2013.Regarding the data source, the value of export from country i to country $j$ is taken from UN Comtrade database (http://comtrade.un.org/). GDP, GDP per capita are taken from World Bank database. All data are expressed in USD. The data on geographic distance is obtained from web Centre d' Etudes Prospectives et d'Informations Internationales (CEPII) (http://www.cepii.fr/). Incomegap is calculated by taking the absolute value in the difference of GDP per capita between country i and country $\mathrm{j}$.

\section{Results and Discussions}

The estimated coefficients for gravity model are presented in table 1. In general, the overall R-squared value (0.7047) indicates that $70.47 \%$ variation of export value between country $i$ and country $j$ can be explained by the explanatory variables in regression of equation (1). 
Table 1. Estimation results

\begin{tabular}{|c|c|c|c|}
\hline \multicolumn{4}{|c|}{ Dependent variable: LnEXPORT $_{i j t}$} \\
\hline Explanatory variable & Coefficients & Std. Err. & P-value \\
\hline LnGDP $_{i}$ & $1.301^{\star \star \star}$ & 0.015 & 0.000 \\
\hline $\operatorname{LnGDP}_{j}$ & $1.122^{\star \star \star}$ & 0.014 & 0.000 \\
\hline LnGDPPC & $-0.027^{\star \star *}$ & 0.016 & 0.121 \\
\hline LnGDPPC $_{j}$ & $0.129 * \star \star$ & 0.017 & 0.000 \\
\hline LnDISTANCE $_{i j}$ & $-1.781^{\star * \star}$ & 0.042 & 0.000 \\
\hline LnINCOMEGAP & $0.113^{\star * *}$ & 0.017 & 0.000 \\
\hline AFTA1 & $0.564^{\star \star \star}$ & 0.136 & 0.000 \\
\hline AFTA2 & $0.202^{* *}$ & 0.096 & 0.025 \\
\hline AFTA3 & $0.388 * * *$ & 0.090 & 0.000 \\
\hline ACFTA1 & $-0.592^{\star \star \star}$ & 0.175 & 0.001 \\
\hline ACFTA2 & $-0.694^{\star \star *}$ & 0.105 & 0.000 \\
\hline ACFTA3 & -0.167 & 0.139 & 0.231 \\
\hline AKFTA1 & -0.069 & 0.201 & 0.729 \\
\hline AKFTA2 & 0.045 & 0.112 & 0.689 \\
\hline AKFTA3 & $-0.366^{\star *}$ & 0.168 & 0.029 \\
\hline AJCEP1 & 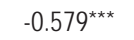 & 0.170 & 0.000 \\
\hline AJCEP2 & $-0.650 * * *$ & 0.104 & 0.000 \\
\hline AJCEP3 & $-0.282^{\star *}$ & 0.132 & 0.032 \\
\hline cons & -30.383 & 0.534 & 0.000 \\
\hline \multicolumn{4}{|c|}{$\begin{array}{l}\text { Total panel (balanced) observations: } 6958 \\
\text { R-squared overall }=0.7047\end{array}$} \\
\hline
\end{tabular}

Source: author's calculation

The estimated results show that most of explanatory variables have expected and statistically significant sign. The coefficients of GDP and distance variables are consistent with the basic hypothesis of the gravity model. The coefficients of two GDP variables which measure the economic size of the exporter and importer countries are found to be positive and statistically significant at $1 \%$. Indeed, larger economies tend to have higher demand for imports and are able to produce more products for exports. This finding reveals that the economic growth will foster the bilateral export among countries in the scope of this paper. Additionally, the positive correlation between GDP per capita of importers and bilateral export can be explained by observing the fact that when the income increases, people tend to consume and import more products. The distance variable has a strong impact on the bilateral export with the expected negative coefficient (1.781), indicating that distance is a trade-restrictive factor. The income gap has a statistically significant coefficient of 0.113 at $1 \%$, which closely follows the fact that ASEAN members tend to trade more with larger economies, for instance, Japan, China, republic of Korea, the United States and EU. The coefficient of the income gap variable is rather small. Therefore, income gap does not affect the bilateral export significantly. In fact, there has been a considerable increase in intra-ASEAN trade volume over the past decade although ASEAN members does not have high gap in per capita income.

All coefficients of three AFTA dummies are found to be statistically significant with positive signs. The positive coefficient of AFTA1 (0.564) reveals that AFTA constitutes an intra-regional trade effect, enhances the exports among member countries and increases economic welfare in ASEAN members. This result is in line with previous studies including Elliot \& Ikemoto (2004), Gulliot (2010) and Sudsawasd (2012). The reason is that trade liberalization in the framework of AFTA has had a long time in effect; therefore, AFTA has had an obvious impact on the volume of trade among member countries. According to IMF (2007), the trade liberalization measures implemented under the AFTA, together with the region's rapid economic growth, have led to significant growth of trade among ASEAN countries. The dummy AFTA2 which represents ASEAN's imports from non-member countries, has a significant positive coefficient, implies an upward trend in imports of ASEAN member countries from non-members. In other words, AFTA does not cause the trade-diversion effect in term of imports. It can be clearly explained by the fact that many ASEAN countries have high export similarity index so ASEAN countries tend to import complementary products from the rest of the world. The coefficient sign of AFTA2 in this paper is different from the result of Hapsari and Mangunsong Carlos (2006), which 
can be explained due to different periods of estimation. Concerning the export creation effect, the coefficient of AFTA3 dummy is found to be statistically significant with positive sign which indicates the expansion of ASEAN exports to nonmember countries. This empirical finding closely follows the previous papers including Kien \& Hazimoto (2005) and Sudsaward (2012). In addition, the positive impact of AFTA on ASEAN's exports to non-member countries can also be explained by observing ASEAN' actual trade that the share of trade volume with the rest of the world including China, the US, republic of Korea, the US and EU has been witnessing an upward trend over years. Another explanation for this correlation is that export-led growth model has been chosen as a useful method of economic growth by many ASEAN countries for a long time.

Unlike the case of AFTA, the estimated coefficients of ACFTA1 and AJCEP1 turn out with negative sign. This implies that those FTAs do not favor intra-ASEAN trade. Indeed, ASEAN countries share the same advantage in laborintensive sectors due to the abundance in labors. Conversely, the trade pattern between ASEAN and ASEAN +3 countries are more complementary. Therefore, trade among ASEAN countries is negatively affected by the implementation of ACFTA and AJCEP.

The negative sign of ACFTA2 demonstrates the trade-diversion effect in terms of imports. Member countries of ACFTA have diverted imports from non-member countries to member ones due to the implementation of ACFTA. In reality, there has been an upward trend in ASEAN's imports from China since the implementation of ACFTA. Moreover, ACFTA3 is found to be statistically insignificant, indicating that ACFTA has not shown impact on ASEAN's exports to the rest of the world. In general, ACFTA causes significant trade-diversion effects.

All three coefficients of AJCEP dummies are significantly negative which implies that AJCEP creates the trade diversion effects in terms of both exports and imports. Japan is one of the largest trading partners of ASEAN countries. Therefore, trade between Japan and ASEAN countries has increased dramatically to make use of preferential commitments in the framework of AJCEP.

For the case of AKFTA, the statistically significant coefficient of AKFTA3 takes the value of minus 0.366 . The negative sign of AKFTA3 implies the trade-diversion effect in terms of exports from member countries to non-member ones of AKFTA. However, the estimation shows that AKFTA1 and AKFTA2 variables are not significant factors in explaining the bilateral trade. The insignificant coefficients of AKFTA1 and AKFTA2 take the value of minus 0.069 and 0.04 , respectively. These results may imply that AKFTA can increase exports among ASEAN members.

\section{Conclusion}

This study applies the gravity model to assess the impact of ASEAN+3 free trade agreements on ASEAN's trade flows, focusing on the trade creation and trade diversion effects. In particular, the paper employs a panel data for bilateral export between 10 ASEAN countries and their 22 main trading partners in the period $2000-2013$. The estimated results show that GDP, GDP per capita of importers and income gap are positive factors that help promoting the bilateral trade. In addition, the empirical findings reveal that distance proxies as a trade-restrictive factor has a strong impact on the bilateral trade. Indeed, the negative impact of distance on trade within this study is consistent with the basic hypothesis of the gravity model.

The results also indicate the positive and significant trade creation effects from reducing and eliminating tariff barriers in AFTA. AFTA has been successful in promoting the bilateral trade not only among countries but also between intra-bloc and extra-bloc countries. In particular, AFTA not only favors intra-ASEAN trade and ASEAN's exports to the rest of the world but also causes no trade diversion effects in terms of imports. In contrast, the implementation of ACFTA and AJCEP negatively affects trade among ASEAN countries. Also, ASEAN's imports and exports to the rest of the world are negatively affected by ACFTA and AJCEP. This correlation can be explained by the nature that there has been a significant increase in trade between ASEAN and China, Japan since ACFTA and AJCEP came into effect. Therefore, there has been a trade diversion effect in terms of both ASEAN's exports and imports of AJCEP and ACFTA. Finally, AKFTA diverts ASEAN's exports to the rest of the world and may increase exports among ASEAN members.

\section{References}

ASEAN Secretariat and World Bank. (2013). ASEAN Integration Monitoring Report.

Cabalu, H., \& Alfonso, C. (2007). Does AFTA Create or Divert Trade?. Global Economy Journal, 7(4).

Calvo Pardo, H. F., Freund, C. L., \& Ornelas, E. (2009). The ASEAN free trade agreement: impact on trade flows and external trade barriers. World Bank Policy Research Working Paper, (4960).

Elliott, R. J., \& Ikemoto, K. (2004). AFTA and the Asian Crisis: Help or Hindrance to ASEAN Intra-Regional Trade?. Asian Economic 
Journal, 18(1), 1-23.

Endoh, M. (1999). Trade Creation and Trade Diversion in the EEC, the LAFTA and the CMEA: 1960-1994. Applied Economics, 31(2), 207-216.

ERIA. (2012). The Integrative Report of the ASEAN Economic Community Blueprint Mid Term Review Project. Economic Research Institute for ASEAN and East Asia (ERIA).

Evenett, S. J. (2012). The Doha Round Impasse. Rethinking Global Economic Governance in Light of the Crisis New Perspectives on Economic Policy Foundations, 111

Guilhot, L. (2010). Assessing the impact of the main East-Asian free trade agreements using a gravity model. First results. Economics Bulletin, 30(1), 282-291.

Hapsari, I. M., \& Mangunsong, C. (2006). Determinants of AFTA members' trade flows and potential for trade diversion. Asia-Pacific Research and Training Network on Trade Working Paper Series, 21, 1-29.

International Monetary Fund (IMF) (2007). Vietnam: Selected Issues. IMF Country Report No. 07/385.

Kien, N., \& Hashimoto, Y. (2005). Economic Analysis of Asean Free Trade Area-by a Country Panel Data. Discussion Papers in Economics and Business, (12).

Kim, K. (2005). The Economic Effects of Forming Korea-ASEAN Free Trade Agreements: The Case of IT Industry.

Lijun, S. (2003). China-ASEAN free trade area: Origins, developments and strategic motivations. Singapore: ISEAS.

MUTRAP III (2010). Impacts Assessment of Free Trade Agreements on Vietnam's Economy. FTA HOR Final Report, Vietnam - EU MUTRAP III.

Nguyen, Anh Thu. (2012). Assessing the Impact of Vietnam's Integration under AFTA and VJEPA on Vietnam's Trade Flows, Gravity Model Approach. Yokohama Journal of Social Science, 17(2), 137-148.

Viner, J. (1950). The Custom Union Issue. London: Carnegie Endowment for International Peace.

Nguyen Anh Thu, Vu Van Trung and Le Thi Thanh Xuan. (2014). Impacts of ASEAN+3 trade integration on Vietnam's trade flows in fishery sector. In proceedings of International Conference on Emerging Challenges: Innovation Management for SMEs (ICECH 2014) Hanoi, Vietnam.

Nguyen Tien Dung (2011). Impacts of ASEAN-South Korea free trade agreement on Vietnam trade. VNU Journal of Science, Economics and Business 27, 219 - 231. (in Vietnamese)

Urata, S., \& Okabe, M. (2013). The Impact of AFTA on Intra-AFTA Trade (No. DP-2013-05).

Park, D., Park, I., \& Estrada, G. E. B. (2008). Is the ASEAN-Korea Free Trade Area (AKFTA) an Optimal Free Trade Area? (No. 21). ADB Working Paper Series on Regional Economic Integration.

Soloaga, I., \& Wintersb, L. A. (2001). Regionalism in the nineties: What effect on trade?. The North American Journal of Economics and Finance, 12(1), 1-29.

Sudsawasd, S. S. (2012). Trade Integration in East Asia: An Empirical Assessment. Modern Economy, 3(03), 319.

Tongzon, J. L. (2005). ASEAN-China free trade area: A bane or boon for ASEAN countries?. The World Economy, 28(2), 191-210.

Yang, S., \& Martinez-Zarzoso, I. (2014). A panel data analysis of trade creation and trade diversion effects: The case of ASEAN-China Free Trade Area. China Economic Review, 29, 138-151.

Yue, C. S. (2004, April). ASEAN-China free trade area. In AEP Conference (pp. 12-13).

\section{Appendices}

Appendix 1. Summary statistics

\begin{tabular}{lccccc}
\hline Variable & Obs & Mean & Std. Dev. & Min & Max \\
\hline Export & 6958 & $2.56 \mathrm{e}+09$ & $7.07 \mathrm{e}+09$ & 1 & $1.22 \mathrm{e}+11$ \\
GDP $_{\mathrm{i}}$ & 6958 & $8.19 \mathrm{e}+11$ & $2.15 \mathrm{e}+12$ & $1.73 \mathrm{e}+09$ & $1.68 \mathrm{e}+13$ \\
GDP $_{\mathrm{j}}$ & 6958 & $1.17 \mathrm{e}+12$ & $2.30 \mathrm{e}+12$ & $1.73 \mathrm{e}+09$ & $1.68 \mathrm{e}+13$ \\
GDPPC $_{\mathrm{i}}$ & 6958 & 19941.9 & 18484.67 & 298.95 & 67555.76 \\
GDPPC $_{j}$ & 6958 & 18967.61 & 17790.45 & 298.95 & 67556 \\
Distance & 6958 & 7982.286 & 4051.583 & 1 & 66611.35 \\
Incomegap & 6958 & 23319.02 & 15938.8 & 505.54 & 16272.36 \\
\hline
\end{tabular}

Appendix 2. List of countries

\begin{tabular}{ll}
\hline Reporters & Partners \\
\hline Brunei, Cambodia, Indonesia, Laos, & Australia, Austria, Canada, China, Denmark, Finland, France, Germany, Greece, \\
Malaysia, Myanmar, Philippines, & Hong Kong (China), India, Ireland, Italy, Japan, Mexico, Netherlands, New \\
Singapore, Thailand, Vietnam & Zealand, Republic of Korea, Spain, Sweden, United Kingdom, United States \\
\hline
\end{tabular}

